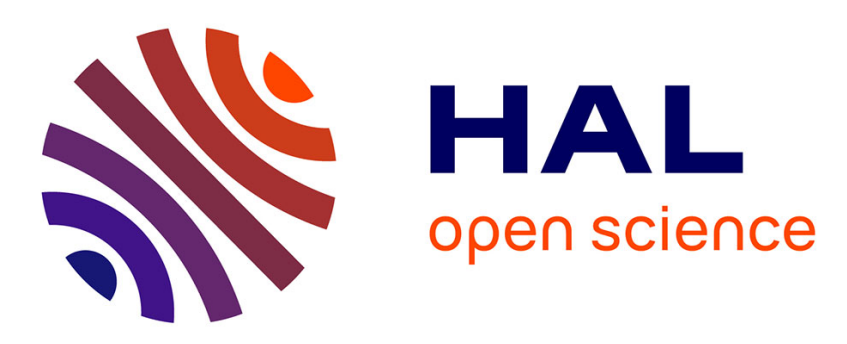

\title{
Unpacking the Figure of the Backpacking Neighbourhood: Phạm Ngũ Lão in the making of Hồ Chí Minh City \\ Marie Gibert, Emmanuelle Peyvel
}

\section{- To cite this version:}

Marie Gibert, Emmanuelle Peyvel. Unpacking the Figure of the Backpacking Neighbourhood: Pham Ngũ Lão in the making of Hồ Chí Minh City. South East Asia Research, 2016, 24 (4), pp.510-531. 10.1177/0967828X16674823 . hal-01579639

\section{HAL Id: hal-01579639 \\ https://hal.science/hal-01579639}

Submitted on 1 Sep 2017

HAL is a multi-disciplinary open access archive for the deposit and dissemination of scientific research documents, whether they are published or not. The documents may come from teaching and research institutions in France or abroad, or from public or private research centers.
L'archive ouverte pluridisciplinaire HAL, est destinée au dépôt et à la diffusion de documents scientifiques de niveau recherche, publiés ou non, émanant des établissements d'enseignement et de recherche français ou étrangers, des laboratoires publics ou privés. 


\section{Unpacking the Figure of the Backpacking Neighbourhood Phạm Ngũ Lão in the making of H ôchí Minh City}

\section{Article information :}

This article corresponds to the publisher accepted version (version 2) of the following reference:

Gibert, Marie, et Emmanuelle Peyvel. « Unpacking the Figure of the Backpacking Neighbourhood Phạm Ngũ Lão in the making of H ôChí Minh City ». South East Asia Research 24, $\mathrm{n}^{\mathrm{O}} 4$ (2016): 510-31.

DOI: https://doi.org/10.1177/0967828X16674823

The final published version is accessible online:

http://journals.sagepub.com/doi/abs/10.1177/0967828X16674823\#articlePermissionsContai ner

\section{Corresponding author :}

Marie Gibert

University Paris Diderot, 5 rue Thomas Mann, 75013 Paris, France.

Email: marie.gibert@univ-paris-diderot.fr 


\title{
Unpacking the Figure of the Backpacking Neighbourhood Phạm Ngũ Lão in the making of H ồChí Minh City
}

\begin{abstract}
Our article aims to understand the participation of the "backpacking neighbourhood" Phạm Ngũ Lão in the current metropolization process of H ô Chí Minh City. This neighbourhood is representative of the Vietnamese "glocalization". By this term, we mean the abilities of local stakeholders to benefit from the opportunities created by an increasingly global economy. These skills are reflected not only in innovations and landscape transformations to attract tourists, but also in "reactivations" based on older urban practices. We question not only the production of specific urban territories through backpacking activities, but also the spatial and social inequalities they generate. By doing so, our intention is to combine tourism studies and urban studies to "unpack" the figure of the backpacking neighbourhood and to go beyond the idea of urban enclaves.
\end{abstract}

Keywords: Metropolization - Tourism globalization - Backpacking economy - Urban production - Local stakeholders - H ồChí Minh City - Việt Nam

\section{Introduction}

For international tourists leaving Tân Sơn Nhất airport (H ôChí Minh City) for the first time, the experience can be tough: the heat, the noisy atmosphere, together with the horde of taxi drivers working for various companies and hotels, can be puzzling. But, in this confusion, one name resonates more strongly than the others: "Phạm Ngũ Lão!". This name is supposed to get the attention of backpackers, who do not have any grand hotel driver waiting for them with a name board.

"Phạm Ngũ Lão" is one of the main arteries of the historical centre in H ôChí Minh City. It is also an administrative ward within central district 1 (Figure 1). But nowadays, this name is highly associated with the H ô Chí Minh City "backpackers area" (the Tây ba lô area in Vietnamese - literally, the "Westerners with backpacks" area). This neighbourhood is characterized by a specific urban landscape, made of rows of minihostels, bars, travel agencies and cheap restaurants. The sharp local identity of this well-known neighbourhood is deeply connected with the development of a "budget tourism" economy. 


\section{Figure 1. Locating Phạm Ngũ Lão at different periods and city scales}

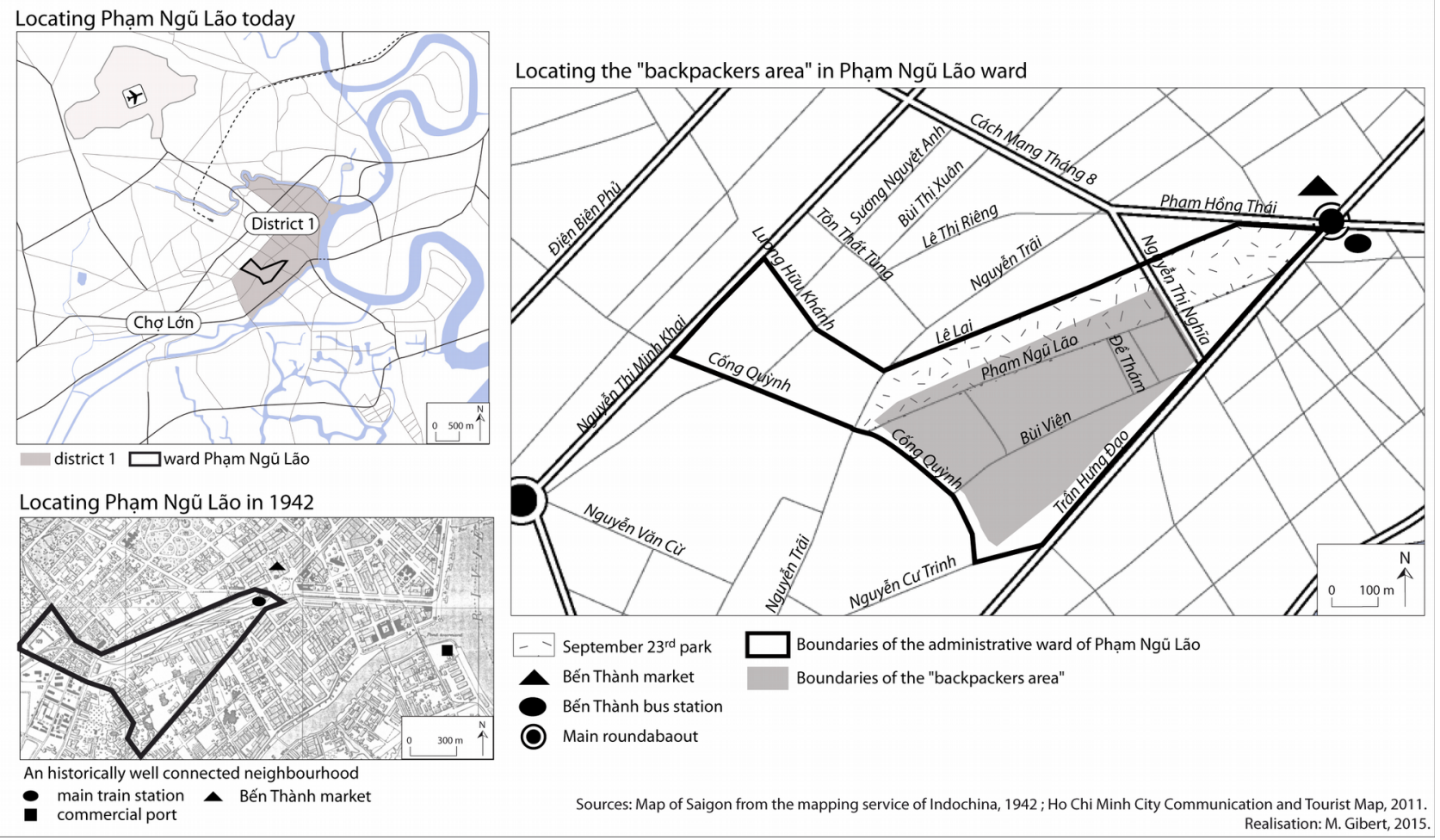

Since the pioneer works of Erik Cohen in the 1970s on what was then called "independent travelling", or even "drifting tourism", many efforts have been made to explore backpacking practices (Cohen, 1973; Richards and Wilson, 2004; Hannam and Diekmann, 2010; Hampton, 2013). Despite the lack of a unique academic definition of backpacking, most authors converge on these criteria: young people (mainly under 40), travelling on a budget for long periods, and aiming to experience local culture without any rigid itinerary (Howard, 2005: 357; Pearce et al., 2009: 10).

Together with India and Nepal, South-East Asia is among the oldest backpacker trails and remains the most popular area as a backpacker destination (Hampton, 2010: 3). This historical development explains the numerous specialized neighbourhoods of the region dedicated to backpackers, beginning with Khaosan Road in Bangkok, Jalan Jaksa in Jakarta, Jalan Sosrowijayan in Jogyakarta or Boeng Kak in Phnom Penh (Howard, 2007, Hampton, 2013). In this regional context, Việt Nam emerged as a new prime backpacking destination in the 1990s, soon after the opening of its economy (Đổi Mới) (Lloyd, 2006). The growing popularity of Việt Nam also converged with the rise of many low-cost carriers in South-East Asia (Hampton, 2013: 24).

If the specificity of backpacking is now well acknowledged in the literature on tourism, most studies continue to focus on the backpackers themselves, on their motivations and practices, and on their various impacts on the host local societies (Richards and Wilson, 2004). Our goal is to renew this approach and to go 
beyond the study of the "impacts" made by tourists. One of our central arguments is that local stakeholders, in their great variety, participate fully in the construction of backpacking neighbourhoods. We will build this argument on a spatial approach of backpacking in the urban context of H ôChí Minh City.

Cities now occupy a greater place among tourism studies, but very few really engage with morphological, architectural and landscape analyses. Besides, backpacking neighbourhoods have received very little attention from urban studies scholars. This resulted in the systematic - and yet under-questioned - use of the concept of "urban enclave" or "bubble" to characterize backpacking neighbourhoods (Edensor, 1998; Judd, 1999; Hottola, 2005; Howards, 2005 and 2007; Lloyd, 2006; Hampton, 2013). By producing an original spatial and ethnographic study of Phạm Ngũ Lão, we want to challenge this consensus and to highlight the strong heterogeneity that characterizes this neighbourhood.

The urban "production" (Lefebvre, 1991) of Phạm Ngũ Lão has to be understood in a complex interplay of local stakeholders - whether they are local private entrepreneurs or representatives of the district public authorities -, and within the geography of their social inequalities. These inequalities differentiate the access to touristic resources among them, according to gender, age, race, income, education or network capacity, and they condition their social and spatial positioning in the neighbourhood.

In this paper, we also consider backpacking as an influential factor of metropolization for H ô Chí Minh City. Phạm Ngũ Lão can be considered as a symbol of the globalization of the country, following a well-known process of hybridization between local and global apparatus (Appadurai, 1996; Bhabha, 1994), also called "glocalization". Beyond its backpacking specificity, Phạm Ngũ Lão allows us to examine the trajectory of a central neighbourhood in the course of the city's metropolization and the unequal competition between its different stakeholders.

The new perspectives we want to offer on the backpacking neighbourhood is made possible by crossing the input and methodology of tourism studies with the tools and research questions of urban studies. This essay is co-written by a geographer specializing in tourism in Việt Nam (Peyvel, 2009), and an urban geographer and a specialist of the contemporary development of H ô Chí Minh City (Gibert, 2014). Therefore, our paper engages in breaking down the barriers in the understanding of the structuring and functioning of backpacking neighbourhoods.

Based on land registers and mapping surveys, we probed into local spatial apparatus at the neighbourhood's scale itself and at that of the blocks and individual buildings. Typo-morphological surveys were completed with more than 30 interviews of local actors, residents and backpackers. These enquiries were conducted in the interviewees' preferred language, mainly in Vietnamese, more rarely English and French. Participant observations were also conducted during a three-week fieldwork based in a local guesthouse in 
August 2014, and completed in October 2014. Previous fieldwork surveys in the neighbourhood had been carried out in April and July 2007, but also in July 2010.

The structure of our paper is as follows: the first part engages with the literature on backpacking neighbourhoods and discusses the necessity to go beyond the concept of the urban enclave. Drawing from metropolitan and postcolonial studies, we therefore claim for a study of Phạm Ngũ Lão as an "ordinary" neighbourhood (Robinson, 2006). Then, in the second part, we explain why Phạm Ngũ Lão can be considered as an archetypal backpacking neighbourhood. Informed by grounded observations and mapping surveys, part three argues that Phạm Ngũ Lão cannot be considered as an enclave despite its strong economic specialization. Based on this previous analysis, the next part engages with the growing heterogeneity of this neighbourhood in the course of H ôChí Minh City's metropolization. Part five explores the "dark face" of Phạm Ngũ Lão in its highly unequal development process. Then, the final part discusses the future of Phạm Ngũ Lão at a time of growing institutionalization and normalization.

\section{Beyond the enclave: engaging with the literature on backpacking neighbour- hoods}

The figure of the "enclave" has early become a classic analytical tool in tourism studies (Pearce, 1989), especially in works dealing with tourism in developing countries which mainly focus on international tourism. This image borrows from the figure of trading posts (comptoirs) in a colonial context, by underlining the isolation and the extraterritorial status of delimited places of encounters between local societies and foreigners. While didactic and visually strong, this image remains problematic because it legitimizes the idea of insurmountable differences between tourists and local societies (Jenkins, 1982; Munt, 1994) and it also acknowledges "an effective isolation from the host local community and economy" (Hampton, 2013: 69). Historically applied to touristic small islands and all-inclusive resorts, the concept of enclave has become a leitmotiv in backpacking studies, together with the "backpackers ghetto" or "touristic bubble" (Judd, 1999). Howards defines the backpackers enclave as follows:

“[an area containing] at least 10 relatively closely-spaced and relatively inexpensive guesthouses/hotels/hostels, of any size, patronized partly by backpackers. An archetypal backpacker enclave would have only drifters customers, would be predominantly tourist-orientated, with clear boundaries, and a definite character, and selfcontained with all traveller activities there" (Howards, 2007: 77). 
Decentring our approach from the only tourists' perspective allows to challenge the consensus on the urban enclave and for highlighting the strong heterogeneity that characterized such neighbourhood and its sociospatial structure. In a postcolonial perspective and acknowledging that all neighbourhoods are part of the same field of analysis, in this paper, we consider backpackers' neighbourhoods as "ordinary neighbourhoods" which are "all dynamic and diverse, if conflicted, arenas for social and economic life" (Robinson, 2006: 1). This starting point allows to revalue the role of local stakeholders in the construction of such specialized neighbourhoods, in the current context of metropolization. We understand metropolization as a process that affects cities in both their forms and functions and is characterized by a concentration of population, activities and wealth. In particular, metropolization integrates cities into the networks of global economy through an increased accessibility to communication networks at various scales. In this sense, tourism participates fully in the metropolization process (Peyvel and Võ Sang, 2016).

By applying such a theoretical framework to the study of the backpackers' neighbourhood of H ôChí Minh City, we also want to pursue the work on tourism entrepreneurs in Việt Nam (Lloyd, 2006 ; Gillen, 2016). Kate Lloyd carried out a geographical analysis to investigate the development of backpacking areas in Việt Nam "through a study of the development of small-scale tour operators who run traveller cafés" in Hà Nội and H ôChí Minh City (2006: 66). Her approach was then representative of a post-Đổi Móri economy, while our 2016 study reveals instead the rise of metropolitan stakeholders in the making of such a neighbourhood, in the transitional urban context of H ôChí Minh City.

\section{Phạm Ngũ Lão, the archetype of the backpacking neighbourhood}

Phạm Ngũ Lão meets the three main criteria to be considered as a typical backpacking neighbourhood: it is well identified by international guides, its landscape is shaped by the tourist specialization, and it is easily accessible, thanks to its central location and the concentration of various transportation means.

A look at different travel guides - including the Australian Lonely Planet, the French Routard, the English Rough Guide, the Japanese Arukikata, and the guide edited by the Chinese National Tourism Administration - shows that Phạm Ngũ Lão is undoubtedly a key place in H ôChí Minh City's contemporary touristic landscape. All these guides map the area with approximately the same boundaries: a trapezium shape of around five hectares, delimited by two main boulevards - Phạm Ngũ Lão and Trân Hưng Đạo - and two other main streets - Cống Quỳnh and Nguyễn Thái Học. The backpacking neighbourhood itself only occupies a small part of the administrative ward with whom it shares the name. (Figure 1) Its beating heart is made up of ĐêThám and Bùi Viện Streets, which gather most of the hostels, shops and restaurants recom- 
mended in international guides. Our own mapping survey confirms that the most specialized place in the neighbourhood is the square block made of two main alleyways between Phạm Ngũ Lão, ĐêThám, Bùi Viện and Nguyễn Thái Học Streets. (figure 2) Trần Hưng Đạo, Cống Quỳnh and Nguyễn Thái Học Streets can be considered as margins in the structuring of the backpacking area.

Figure 2. Localising the touristic economic sector in Phạm Ngũ Lão

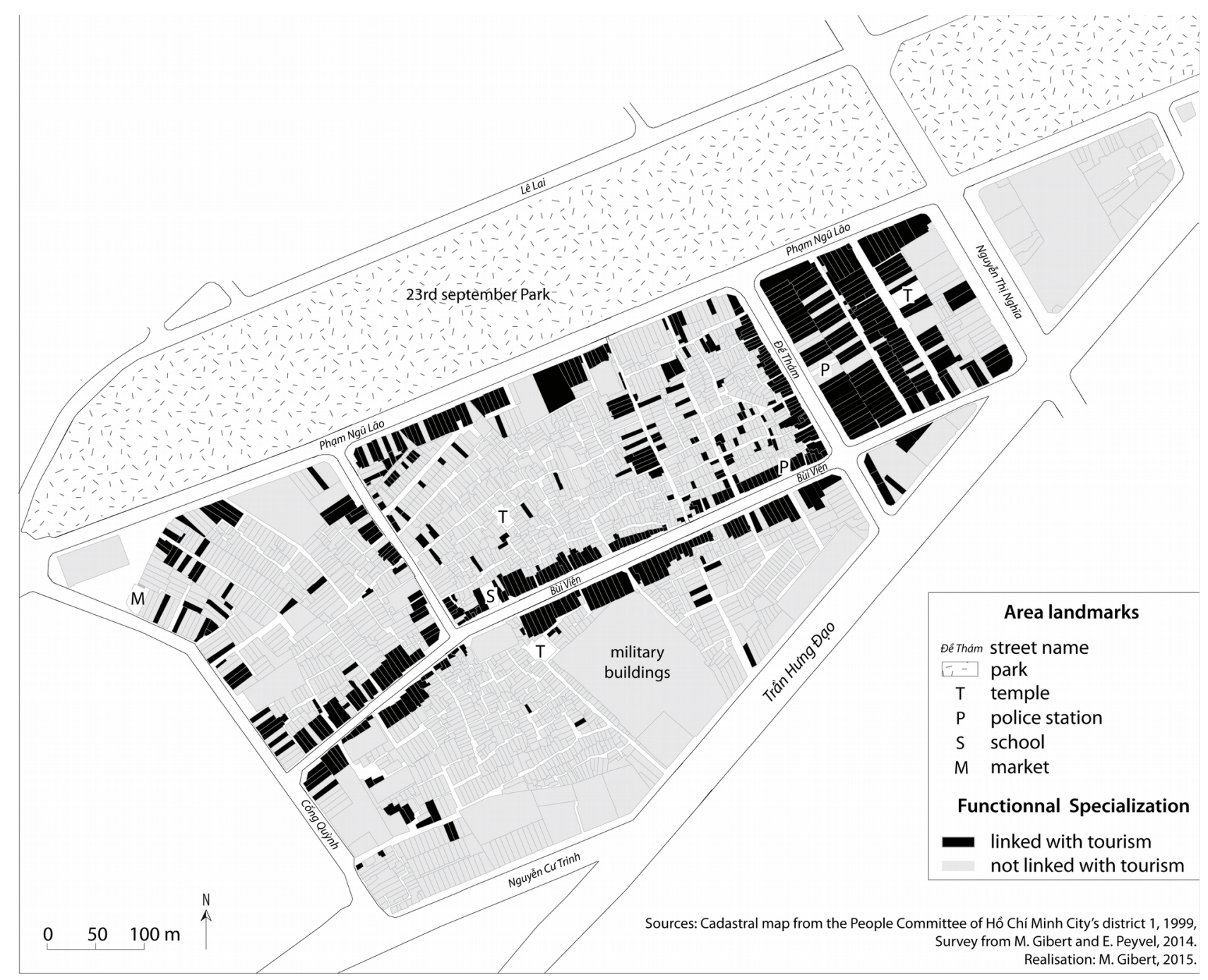

Touristic activities have generated a specific type of landscape in Phạm Ngũ Lão. The neighbourhood offers backpackers the expected services to organize their travels, but also amenities that allow them to negotiate their daily lives in a more or less autonomous manner (O'Reagan, 2010). Its economy is fundamentally in tension between the mobility and the anchoring of backpackers. The neighbourhood concentrates travel agencies and transport services, but also mini-hotels and guesthouses, cheap restaurants and bars, grocery stores, laundries, and abundant day and night entertainment (souvenir shops, tailors, DVD shops, spas and massage salons, nightclubs, sex and drug trade) (Figure 3). These specialized services provide backpackers with all they need in a contained and accessible area. 
Figure 3. Towards a typology of touristic activities along Bùi Viện Street

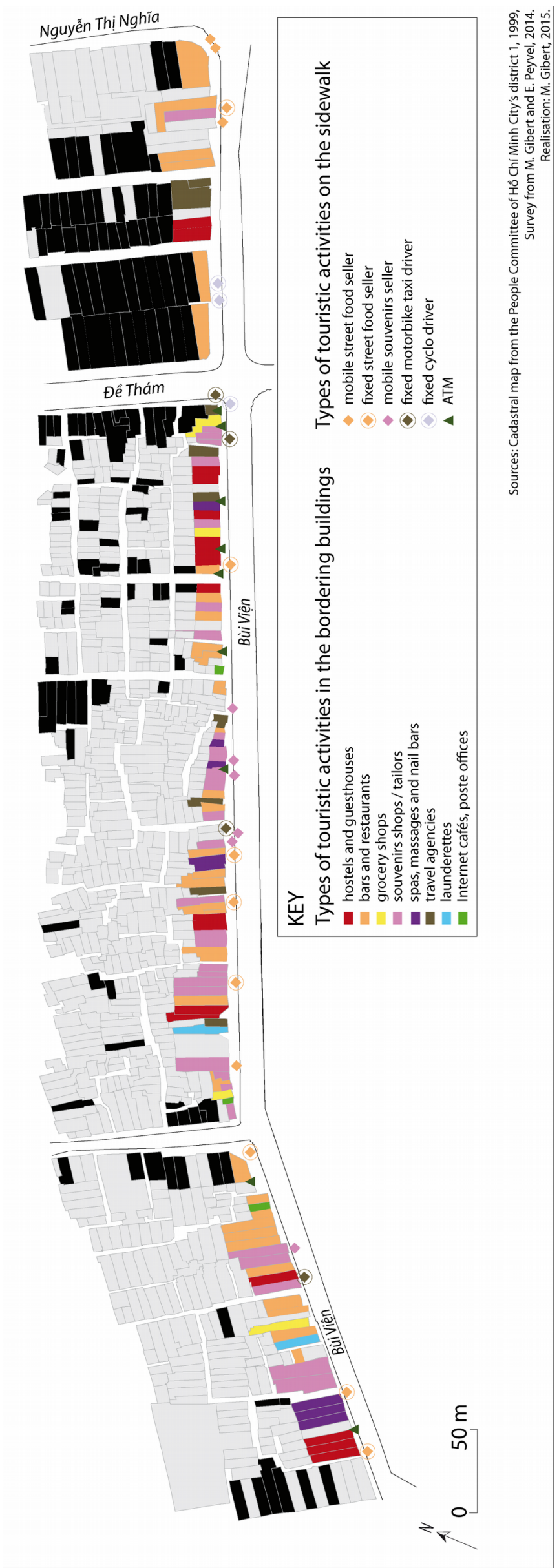


This economic organization provides a compelling strong visual landscape. Signboards that are almost systematically translated into English have become a landmark. Chinese, Korean and Japanese translations have now appeared, echoing the renewed composition of international backpacking tourists. A few French references recall Indochina. The neighbourhood is also filled with global tourism labels: storefronts display quotes from famous travel guides, or websites, such as Tripadvisor. Logos for credit cards are also notably present. The Phạm Ngũ Lão landscape is particularly recognizable at night: the sidewalks, bars and terraces are busy and lighted by numerous signboards, flashy neons or red lanterns, indicating the erotic dimension of the neighbourhood (Figure 4). This use of neons at night is very characteristic of this neighbourhood in H ô Chí Minh City, but it undoubtedly plays on the evocation of other famous Asian metropolises, such as Tokyo, Hong Kong, Seoul or Bangkok, all well-known for their lit-up urban landscapes, swamped with colourful neons. Phạm Ngũ Lão has also acquired great visibility at the metropolitan scale due to its social, racial and gendered attendance. White people are over-represented compared to other neighbourhoods. The presence of beer places (bia hoi) and the economy of prostitution and drugs also induce a high masculine ratio (see part $5)$.

\section{Figure 4. The vibrant urban landscape of Phạm Ngũ Lão at night}

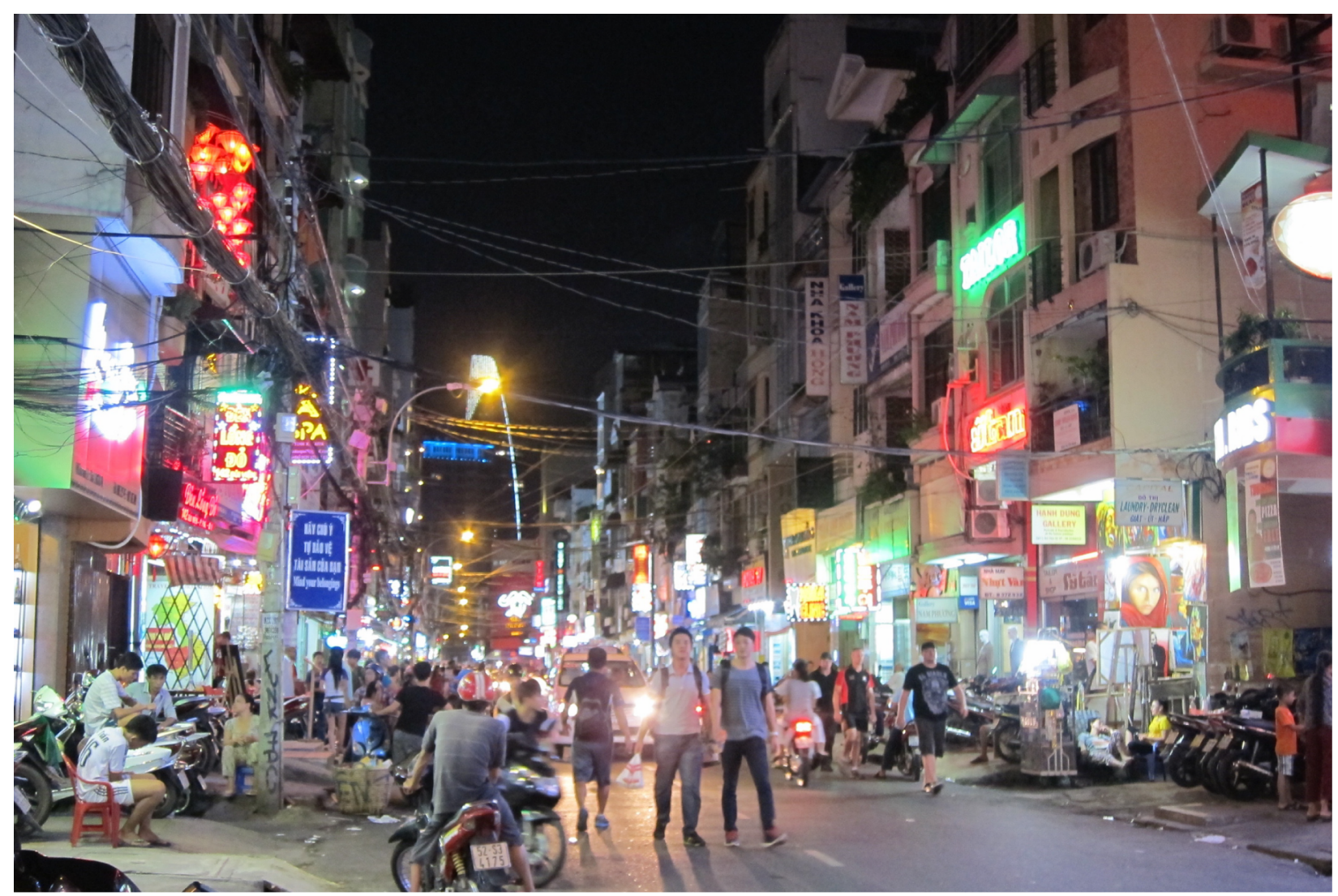

Source: M. Gibert, 2015. 
The last typical criterion for characterizing Phạm Ngũ Lão as a backpacking neighbourhood is its central location and high connectivity, from the local to national scale. During the colonial period, the area was surrounded by the main train station, the harbour and the iconic Bến Thành market (Figure 1) - key places for what can be considered the "first globalization" of Việt Nam through colonial trading posts and transnational city connections. This also explains the success of the zone during the Việt Nam War: Phạm Ngũ Lão was much appreciated by American soldiers on leave. This period prefigured the current globalization of the neighbourhood. The multiplication of cheap rooms to rent to American soldiers was a herald of the budget tourism specialization to come with the economic opening of the next decades.

Today, international backpackers use Phạm Ngũ Lão as a base from which they can explore the rest of the city and the country. This node role is facilitated by the strategic location of the neighbourhood, close to the historical city, in the heart of the transport network. From the historical centre, many tourists join their Phạm Ngũ Lão hostel on foot or by taxi (car or motorbike): this shows the permeability of the zone and its inscription within a wider touristic landscape. At national and international level, Phạm Ngũ Lão provides backpackers with an extensive transport offer (figure 5): it includes a low-cost open ticket that grants access to a night bus that stops at the main national touristic sites, distributed by many travel agencies. More generally, these agencies facilitate the logistics of touristic mobility, in particular the administrative and linguistic side, such as obtaining a visa or finding a guide. 
Figure 5. Phạm Ngũ Lão, a node in the regional and national touristic mobility system

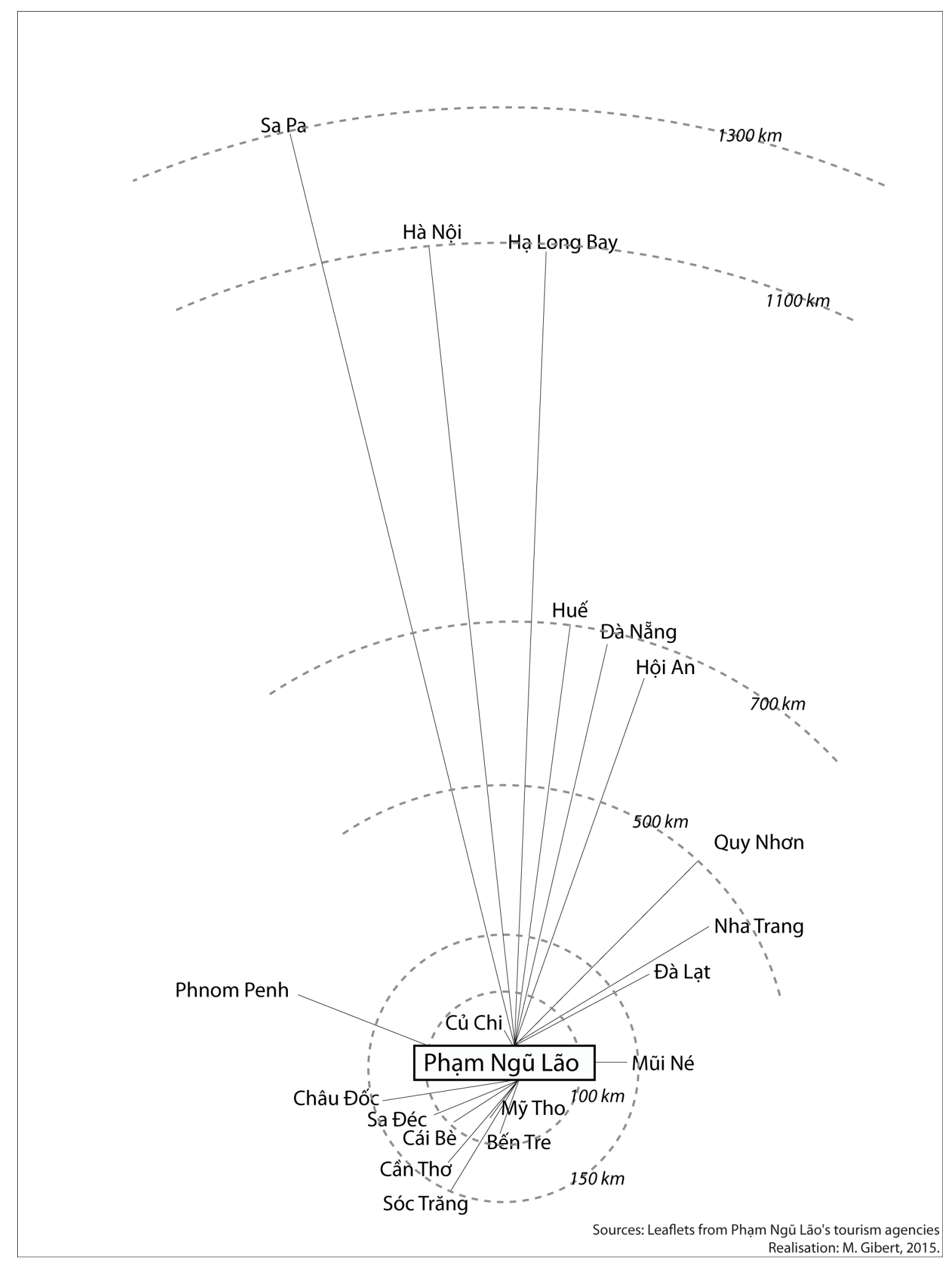




\section{A functional specialization within an ordinary Vietnamese neighbourhood}

\section{The production of a specialized neighbourhood}

If Phạm Ngũ Lão appears as a typical backpacking area, it is because local stakeholders have been successful in adapting to the needs of backpackers and their diverse habits. This adaptation can be read as a form of "glocalization", a hybridization of both Vietnamese services and global tourism apparatus (Appadurai, 1996; Bhabha, 1994). Accommodations and catering services are organized according to this logic. Nhà nghỉ (literally "houses for sleeping") are run in parallel to the figure of the freak hotel and guesthouse, that provide single rooms with or without breakfast. Bia hoi $i$ are cheap beer bars, popular for both Vietnamese men and tourists. Corm bình dân, cheap take-away street food very popular in the Vietnamese cities, is particularly attractive to backpackers. Grocery stores also adapt to the demand by including shelves for specific food and hygiene brands. Laundry services are also provided, ranging from hand-washing by a nhà nghỉ resident or a guesthouse employee, to shared washing machines belonging to landlords or their relatives, and formal launderettes in boutiques offering fixes prices and rules.

This innovative way of appropriating global tourist economy by local practices is also notable in the sector of communications. People have understood the crucial role of the Internet for backpackers in resolving the tension between mobility and anchorage: social networks, emails, etc. allow them to keep contact with family and friends, while blogs and Internet forums help them to plan the rest of their trip. Therefore, they are extending wifi coverage and opening Internet cafés. In order to further facilitate communications, some phone shops allow customers to unlock foreign mobile phones and sell cheap local SIM cards with phoning credit. These services are also provided in small grocery stores, news-stands or cafés, or simply on the sidewalk, where Vietnamese people are used to buying them.

Means of transportation are also representative of this process of glocalization. In Phạm Ngũ Lão, backpackers could use three types: Xe ôm (taxi motorbikes), a typical Vietnamese means of transportation, that offer quick and cheap rides; regular taxis that are more comfortable and safer, but also more expensive and slower; and finally, motorbike rentals that offer the use of the most popular vehicle of the city and registration documents. The location of these services is governed by a visibility gradient: while $x e$ ôm are preferably stationed on the sidewalk and at crossroads - so long as they can negotiate their presence with their colleagues and the police -, taxis (most often employed by big companies like Vinasun, Mai Linh or VinaTaxi) can be found on major streets. The location of motorbike rentals is more complex, depending on their degree of formality: if it is a service provided by a well-known travel agency, it will be very visible on large streets. However, many motorbike rentals are owned individually. For instance, a family motorbike can be periodic- 
ally rented to tourists. These ones are not declared and are found along alleyways, displaying a "motorbike rental" sign, or sometimes simply "thuê một xe máy". This principle of visibility has led to consequences: while most xe ôm, taxis and formal motorbikes renters in travel agency are men, informal motorbikes renters tend to be women, since family motorbike rentals are part of a domestic economy.

Even travel agencies result from this glocalization process. Phạm Ngũ Lão is where Sinh Café first appeared, a touristic innovation that now serves as a model in the country. First named Sinh Ba Lo, this lowcost travel agency was created in 1991-1992 by a couple of Vietnamese restaurant managers. Six years after the Đổi Mới, moving around in Việt Nam was still a challenge ${ }^{1}$. With their backpacking clientele desperately seeking advice and assistance, restaurant owners progressively moved to touristic activities as a source of income. In 1994, Sinh Café offered tours in the South and Centre of the country. In 1995, they opened an office in Hà Nội. Their success relies on a low-cost open ticket that grants access to comfortable night buses. Many travel agencies based on that model flourished, like Kim Café, founded by a former Sinh Café employee².

These combined activities show that in less than twenty-five years, tourism has flourished into a durable economy that has deeply transformed the urban landscape. Phạm Ngũ Lão demonstrates the profitability of backpacking, although it is solely based on low-cost practices (Scheyvens, 2002; Hampton, 1998). However, that does not mean that all local stakeholders benefit from it equally.

\section{Phạm Ngũ Lão as an "ordinary" Vietnamese neighbourhood}

Despite its instantly recognizable landscape, the specificity of Phạm Ngũ Lão has to be qualified. Its historical development, for instance, is very representative of the historical urbanization process of H ô Chí Minh City.

The Phạm Ngũ Lão area was first designed and divided into plots during the colonial period, at the end of the $19^{\text {th }}$ century. The place was formerly known as the "Boresse swamp". At that time, the structuring of the urbanization process began with the planning of main arteries, such as Phạm Ngũ Lão Street and Tr ân Hưng Đạo Boulevard. These arteries were supposed to guide urban development. But the turbulent urban history of H ô Chí Minh City, together with the high demographic pressure from the 1940s onwards, explain the emergence of an uncontrolled densification process along - and more and more behind - the main planned axes. This process went with the multiplication of very vast urban blocks only served by narrow alleyways, along which tube houses are aligned (Gibert, 2014; Gibert and Pham Tai, 2016). This urban morphology allows very high-density rates $^{3}$ and is still the prevalent pattern in the city today. Nowadays, Phạm Ngũ Lão is still in keeping with this dominant development model of the city. The specialization in

1 Travel license was only abolished in 1993 for instance.

2 Interview with Nguyễn Hai Ninh, manager of the Sinh Cafés in Phạm Ngũ Lão, 14/04/2007. 
backpacking activities did not result in any morphological change. On the contrary, the concentration of activities on main streets' frontages is also a classical pattern in the urban functioning of H ôChí Minh City.

If the urban fabric of Phạm Ngũ Lão is not outstanding, neither is its functional specialization. The economic specialization of the neighbourhood reminds us of the corporation model, inherited from the Chinese classical trading city (Chow 2015). In Hồ Chí Minh City, many alleyways' neighbourhoods are characterized by the weight of a trade community (Quỳnh Trân and Nguyễn Trọng, 2007). This model allows the inhabitants to share their tools and skills while benefiting from a professional reputation at the metropolitan scale. It is for example the case of the "jam producers" neighbourhood in ward 1 of district 3, but also as far as lanterns production in ward 9 of Tân Bình district. Thus, Phạm Ngũ Lão's specialization on international tourism activities shows the reactivation of an ancient city model, taking advantage of new economic opportunities offered by the Đổi Móri.

\section{Phạm Ngũ Lão from inside: Inequalities, competition and discrimination}

Phạm Ngũ Lão is not a homogeneous neighbourhood. Not all the inhabitants are involved in the touristic activities and among those who are, there are many different ways of getting involved. In order to study the neighbourhood in its diversity and in the depth of its local urban fabric, we conducted surveys and produced plans of the sector at different scales.

\section{The spatial inequalities of touristic investments}

Our first survey (Figure 2) was led in the whole neighbourhood: it clearly shows its boundaries and the opposition between the main streets and the inner blocks and their alleyways. This binary distribution recalls the importance of the couple front/behind, as well as inside/outside (nội/ ngoại), in the Vietnamese spatial representations (Harms, 2011).

Furthermore, crossroads - especially those of ĐềThám / Bùi Viện and Phạm Ngũ Lão / Đ êThámare core elements of the touristic landscape. They welcome the most famous bars and nightclubs, such as the "Crazy Buffalo" and "Allez Boo", and are particularly visible due to their massive advertising billboards. Many street sellers also occupy the sidewalks in these zones, on a fixed base (Figure 3). Their centrality is even more visible at night, when adjacent bars set up tables and chairs along the sidewalk. This centrality is another core characteristic of the urban fabric of H ôChí Minh City: in a city with very few plazas and open spaces, they are the most popular and busiest public places (Gibert, 2014).

3 The average population density in the Hô Chí Minh City urban districts was 12450 inhabitants / km² in 2013 (Statistical Yearbook of H ôChí Minh City, 2013). 
This exploratory survey was complemented by a more sophisticated one, at the scale of a smaller block of about 600 plots of land and houses, at the corner of Đê Thám and Bùi Viện streets (Figure 6). Its goal was to specify the gradient of investment in tourism for each building. To do so, we defined different criteria, which we examined visually. The first criterion was the display and advertising of the touristic service: are there any advertising billboards? If there are, in which languages? Are there any international labels displayed? Are there any touts calling for clients? Any orienting maps ahead of the shop? Another criterion was the investment in materiality and spatial arrangements in a touristic perspective. Does the touristic activity invest the whole building or only a part of it? Is there any specific furniture displayed or any effort made on the decoration or work outfit for the employees? The combination of these criteria enabled the distinction of four classes, from no touristic activity at all to a total dedication of the building to this function, and in between, minor and main investment.

Figure 6. Highlighting the gradient of investment in tourism between streets and alleyways of Phạm Ngũ Lão

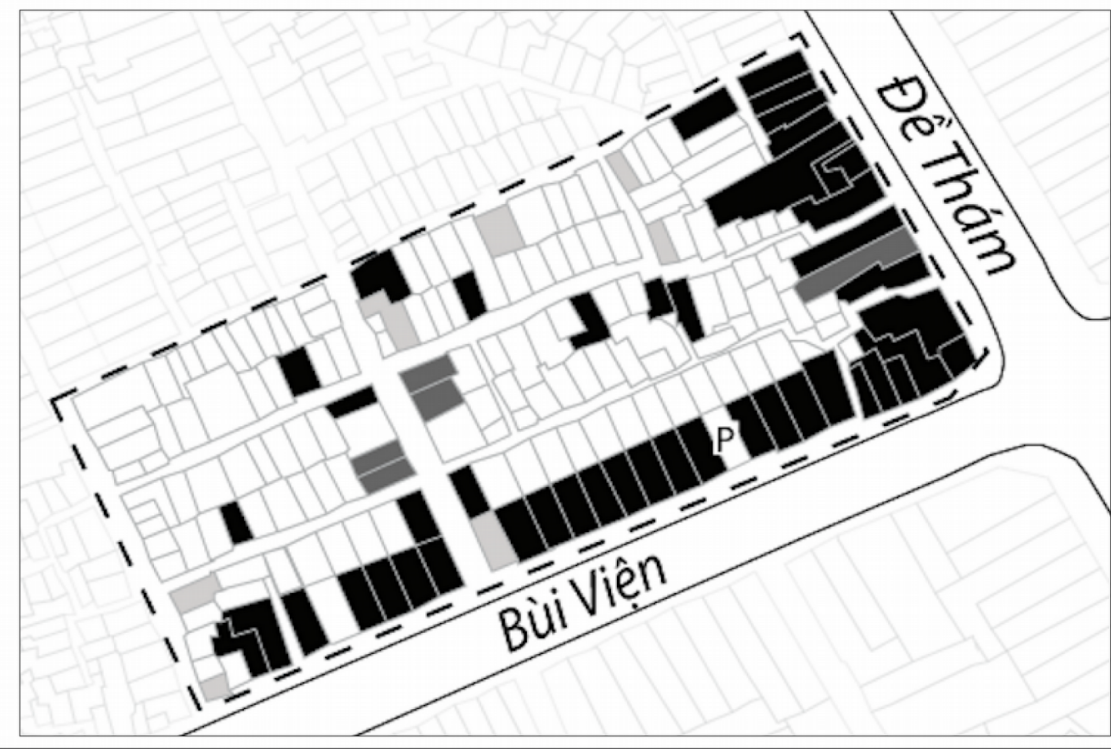

KEY

Bùi Viện street name

i.

building entirely dedicated to tourism

main investment in tourism

minor investment in tourism

no investment in tourism

Survey from M. Gibert and E. Peyvel, 2014. Realisation: M. Gibert, 2015.

Figure 6 helps specify the outside / inside gradient of touristic investments. Inside the block, the larger the alleyway is, the more likely it is to welcome touristic services. In Vietnamese cities, the value of the land is directly connected to the commercial potential of the street the house opens onto. The Vietnamese expression "nha mặt tiên" designates a house localised on a frontage street. Interestingly, the word "tiên" also means "money" in Vietnamese.

At the building scale itself, a gradient of investment can also be observed. Touristic activities are more likely to occupy the front room on the ground floor, while rooms situated in the back and upstairs often 
remain dedicated to private and "back office" activities. In Vietnamese spatial practices, buildings are structured according to the street: the distance to the street commands the layout and the functions associated to each room in the house, through a succession of thresholds. The entrance room constitutes the pivot of this spatial apparatus: it creates an interface between public and private, commercial and domestic activities. It is also considered as a showcase of the residents' offerings. Many residents involved in the tourist economy only invest in the front room, while the back and upstairs rooms remain unmodified. Generally, only main hotels, shops and restaurants located on main streets are entirely dedicated to the tourist economy: the landlords sometimes live in more suburban areas to maximize the profit of their valuable land.

This gradient between front / behind, as well as in / out is even more visible at night: while touristic buildings are very well lit, private houses remain in the dark. Even on a Saturday night, when ĐêThám and Bùi Viện are very colourful and noisy, the inner alleyways of the block remain very quiet.

\section{From transnational investors to hawkers: unpacking the hierarchy of the back- packing economy}

Spatial inequalities are inherently social inequalities. This can be observed at three levels. Firstly, at the neighbourhood level, there is an opposition between front office stakeholders in main streets and back office stakeholders in alleyways. While shops situated on the busiest streets act as showrooms, back-office activities they command remain in alleyways. They include cooking and washing-up activities for bars and restaurants, but also laundry or tailoring. In that sense, large streets and adjacent small alleyways are complementary, but also unequal: money, owners and orders come from large streets, while subalterns are relegated to back alleyways. It is also revealing that Allez Boo, Crazy Buffalo and Go2, the biggest bars and most famous landmarks of the neighbourhood belong to the same Vietnamese owner ${ }^{4}$.

Furthermore, since the property is cheaper on alleyways, they are used for cheaper services: freak hotels, small restaurants and popular entertainments. All these are less signalled, sometimes lacking proper signposts and translations at the entrance. On the contrary, large street services are consistently more internationalized and expensive. This mechanism explains why subaltern services are sent further back. This is particularly true for women, who occupy most subaltern positions, as a 34 year-old tailor told us. She opened a shop in an alleyway next to Bùi Viện. On the wall, a simple sheet of paper on which is written "laundry, repair, clothes":

4 Joint interviews conducted between 2014 and 2016. 
"I have been renting here for 3 months, I live above the workshop. I worked 10 years in a better situated shop, directly on ĐêThám, but my business partner went to Australia and it became too expensive for me to pay the rent."

The visibility of her former activity allowed her to establish an address book with customers she continues to work for. Without that, the localisation of her current activity would be too disadvantaging. This example shows how the backpacking activity has increased the value of the neighbourhood. Nevertheless, the higher value of land translates into higher land pressure that weighs foremost on the weakest actors. They have difficulties to benefit from tourism since they are employees rather than employers, tenants rather than owners, executors rather than deciders, women rather than men (Ariey-Jouglard, 2011).

Secondly, on the international level, social inequalities have been linked to the globalization of the actors of tourism since the Đôi Móri, particularly the connections with Vietnamese Overseas. Surveys revealed a strong link between the success of a business and its personal ties with foreigners. Some foreigners invest directly in the neighbourhoods to create a brand. In 2007, Gingko, an ethical clothing brand managed by a French-Vietnamese couple, opened its first shop in Phạm Ngũ Lão. There are now nine shops across the country.

Beyond the most famous success stories, some family-run micro-businesses based on mixed marriages have also turned their experiences of diaspora into a resource for tourism. The case of Miss T. is instructive. We met her in her alleyway. She overheard our foreign language and came to us to offer a room. We grabbed the opportunity to discuss her activity: she has been living in the neighbourhood for over 28 years and owns three houses in alleyways, in which she rents 15-dollar rooms. She grew up in Vientiane (Laos), where she studied at the French high school. She lived one year in Paris, where she still has a nephew. She is also married to a Canadian and has family in the United States. This explains her fluent French and English and also her better understanding of backpackers' needs, lifestyles and representations of Việt Nam. The trajectories of other respondents confirm the ability to make profitable usage of international ties. These testimonies show how cosmopolitan family businesses have an edge in the tourist economy.

Some stakeholders of the backpacking economy remain subalterns. Hawkers for instance are condemned to roam the streets because their activities are informal, and possibly illegal. Street vendors walk the neighbourhood to sell cigarettes, paper tissues, souvenirs and newspapers, biscuits and candies. Their work is tedious: they carry heavy loads all day under the scorching sun. The right to settle in front of a house or on the sidewalk has to be negotiated with owners and the police, and only a few are granted access, like a candy vendor we met, who was authorized to stay only two days per week. The rest of the time, she works in dis- 
tricts 1 and 3 and lives in the Gò Vấp District ${ }^{6}$. Gender and age are relevant to understand stakeholders subalternity: most of them are women, sometimes very young with little formal education; others are older women desperately searching for a salary. A 60-year-old vendor - selling cigarettes and tissues - that we met at the entrance of an alleyway on Bùi Viện Street explained that she had been working there for four years, since she retired and lost her husband ${ }^{7}$.

The poorest are beggars. They are often young girls, sometimes carrying a baby and asking tourists for money in the evening. This risky business exposes them to violence. Besides this, they are subject to police harassment, since begging is prohibited. It is therefore extremely difficult to interact with them, but a study carried out in 2005 shows that they are comprised not only of broken families, but also of the floating population of migrants, who are not officially registered and marginalized from the urban economy (Duong and Kenichi, 2005). In the backpacking economy of Phạm Ngũ Lão, subalternity and spatial marginalization go hand in hand.

\section{Shadow workers in the light of Phạm Ngũ Lão: revealing the informal produc- tion of the metropolis}

Phạm Ngũ Lão is representative of the production of the city in the global South (Parnell and Oldfield, 2014). Local stakeholders, whatever their administrative statuses and official recognition are, participate actively in the metropolization of the city through their connections to transnational networks, even though these connections can be informal, and sometimes illegal.

The spatial inequalities among Phạm Ngũ Lão's stakeholders reveal complex spatial gradients, from formal to informal, legal to illegal, visible to invisible. Even legal activities are sometimes processed informally: laundry for instance can be an undeclared backyard trade or a well-recognized agency service providing multiple machines. The same goes for souvenirs, equally sold by shopkeepers or hawkers. The legal dimension of these activities is complex. Most of them are perfectly legal (catering, accommodation, souvenir trade, etc.), others mix legal and illegal (a souvenir boutique providing pirate DVD copies), and others are totally illegal, such as the sex and drug trade. The result is a complex play to gain visibility for tourists and generate income, while staying invisible to police surveillance.

Prostitution is not advertised explicitly, as is the case for instance in Patpong neighbourhood in Bangkok, but touts' and sex workers' solicitations signal this activity in places like bars, massage salons,

6 Interview conducted at the entrance of an alleyway, on the 11/08/2014.

7 Interview conducted on the 11/08/2014. 
karaoke or hairdressers. Some landmarks help to identify the red district: shaded storefronts with dubious names such as Me and You, red lanterns, slogans like «no money no honey » or « ugly but good», etc.

This ambivalence also sheds light on the making of the city and the way touristic activities are put forward, selected and regulated according to a notion of invisibility. Illegal activities are made invisible by avoidances and camouflage tactics. Semi-structured interviews with tourists have demonstrated that drugs are sold during false motorcycle taxi rides:

"A guy comes to you when you're on the sidewalk, he offers marijuana mostly, but it can also be opium or cocaine. If you're willing to, he shows you the xe ôm working with him, if it's not directly him. Once you're at the rear of the motorbike, he fakes a taxi ride, often just going around the park, and then he gives you a sample, so you can try it. When he drops you, instead of paying the ride, you pay for the drugs. Or else, the $x e$ ôm goes a bit further, calls one of his friends who handles the merchandise at a crossroad." (S., 35 years old)

Prostitution is exclusively directed at male heterosexuals, or homosexuals on rare occasions, but almost never to women or couples. The neighbourhood operates in a clear sexualized and gendered manner, and the later it gets, the more sexualized it is. The exhilarating risk of taking drugs performs male heterosexual identities, alone or with friends, by associating a certain manhood to initiatory touristic experiences, that are facilitated by the physical and mental distance to daily norms (Chapuis, 2012). On this basis, we can also qualify this neighbourhood as a "sexscape" (Kay Hoang, 2015), in reference to Appadurai's scapes (1996), that designates a global sexual landscape comparable to other famous red light districts in the world, like those of Amsterdam and Bangkok. This sexscape is rooted in both colonialism and globalization. Prostitution was present in Phạm Ngũ Lão as soon as French colonization (Tracol-Huynh, 2013: 515-516). The exoticization of Vietnamese women and the racialization of their bodies and desires have continued with American soldiers up to 1975 (Kay Hoang, 2015). Today, sex-workers use this exoticism as an economic resource for white male tourists.

Prostitution and drugs are considered as "social evils" (tệ nạn xã hội) and are officially prohibited by the socialist regime. This explains why Phạm Ngũ Lão is regularly in the headlines of local newspapers, accusing the neighbourhood of being a den of violence. Fights are relatively frequent, particularly between tourists and touristic professionals, and among tourism stakeholders. This violence is proof of power relations between male and female, white and racialized people, illegal and official actors. The regulation of drug and prostitution activities is closely linked with organized crime. For example, henchmen ensure prompt payment of services and intervene when tourists do not want to pay Vietnamese sex workers. Those violent interventions are not free: girls pay both to gain access to tourists and also to be protected (Kay Hoang, 2015). 
Struggles for the control of territories also oppose city authorities with the stakeholders of illegal activities, but in a very ambivalent way. This economy is a key development factor of tourism, and a source of personal enrichment with corruption (Koh, 2001; Kay Hoang, 2015). This difficult balance between regulation and a hands-off approach has to meet around the security and reputation of the neighbourhoods, which is vital for any touristic activity, whether it be legal or illegal.

\section{“Same same, but different": towards a mainstream backpacking neighbourhood}

Today, Phạm Ngũ Lão is becoming less and less a neighbourhood for drifters, and more and more a mainstream cosmopolitan area of H ô Chí Minh City. This situation results from the convergence of three urban dynamics: an increased competition between tourism operators leading to a quality upgrade; the increasing mutation of the backpacking neighbourhood into a cosmopolitan leisure area; and the recent reinvestment of the municipal authorities.

\section{The formalization of backpacking by local stakeholders: unequal skills in the upgrading}

Phạm Ngũ Lão is currently upgrading its overall quality: the number of freak hotels is diminishing in favour of modest but well maintained hotels and guesthouses. The same goes for all tourist services.

There are many reasons to explain this quality upgrade. Firstly, competition in a restricted perimeter between many actors tends to favour the highest quality. A growing preoccupation among shopkeepers is to reassure customers about the quality and authenticity of their products. Some of them display billboards on their storefronts, stating "nhắp khảu an toân, chắt lượng cao" (security of importations, high quality). Secondly, backpackers are skilled travellers who share their opinions on websites, like Tripadvisor. This forces local stakeholders to offer competitive deals, because their reputation can be easily broken. Finally, the neighbourhood is now relatively established. The euphoric period that took place after the opening of the country in 1986, and after the end of the American embargo in 1994, is over. The overall standards of living are now higher and the same is true for the prices of touristic services. Therefore, tourists have grown more demanding and tolerate less improvisation.

This growing quality is also a testimony to the skills of the local actors and of their flexibility to the changing market of backpacking. The challenge is to communicate with backpackers in order to better understand their mindset and requirements in terms of comfort and services, which involves linguistic language, digital and marketing skills. Those skills and know-how are acquired not only at school, but also empirically, in the field. 
This quality upgrade reveals and deepens the inequalities between the actors of the backpacking economy, making it always more discriminating. The influx of foreign investors, in particular globalized food franchise operators, like Burger King or Starbucks, have introduced delivery services and products that are increasingly difficult to compete with, especially for micro-entrepreneurs and family businesses. The employees of these new establishments receive training in foreign languages, allowing them to adopt appropriate welcoming behaviour, following international standards. This dynamic is not specific to Phạm Ngũ Lão. From the case study of the Town 1770 in Australia, Peter Welk established a link between the normalization of a backpacking neighbourhood and the normalization of the backpacking activity itself, which is increasingly managed with norms coming from the corporate world. This phenomenon blurs the line between conventional and backpacking tourism, which becomes simply a distinctive brand in the tourism market (Welk, 2010).

The semi-directive interviews we conducted show the growing difficulties met by the smallest and least experienced entrepreneurs as Phú, 23 years old. He lives alone with his mother who owns a house transformed into a modest guesthouse at the back of an alleyway:

- "My mother worked as teacher in a primary school. In order to supplement her pension, she wanted to get into the tourism business because of the neighbourhood, but it doesn't work so well. She rents a few motorbikes and a friend helped us improved the house to open some rooms for guests, but it not really working.

- Would you have done things differently?

- My mother has her own project, but I wouldn't have done like that. She doesn't speak English, me a little bit. I learnt at school, I don't speak very well, but I try to speak with tourists, they explain things to me. The furniture is too basic, there's just a bed. I saw websites of the others, I know how it is. We don't have a website. And she's not very friendly. I would like to offer rides with my motorbike and maybe include the price of breakfast in the price of the room, but she doesn't agree with all that".

The half-hearted situation of this family contrasts with other stakeholders, who succeed in capitalizing on skills and capital, like the owner of the BR Hotel, a 30-year-old woman who shared her story in fluent English:

- "What did you know about tourism when you began? How did you start?

- I studied at the Saì Gòn Economic Business School, where I quickly chose hotel management as a speciality. My father worked for a Japanese tourism company. During my first year at the university, we demolished our house and built our first hotel, in 2009. Today, I 
am the owner. Business has been good, we identify customer's expectations and we are well referenced, especially on Tripadvisor. Today, we have 14 employees in 4 hotels [built in 2011, 2013 and 2014].

- Did your personal savings pay for those new constructions?

- For the first one, yes, but today, we have a bank loan. The previous hotel pays for the next one.

- And now, where do you live?

- We don't live on site anymore. We are in district 4. But I work here everyday, it is what makes the quality of the service: follow-up. I speak with tourists, I oversee the work.

- Do you often travel?

- I have already travelled in Việt Nam, Thailand, Singapore, Korea and Malaysia. It gave me some ideas for my own business".

The success achieved by this family could be explained by the capitalization of profits, with benefits consistently going back into the business, but also by the acquisition of various skills: early exposure to foreign tourists in a professional framework, good higher education in tourism, travels that she regularly made as a tourist: everything that helps her understand customers and the ways other professionals do things. Good relationships with local authorities also participate to the success of the business (Bennett, 2009) and are also discriminating.

\section{From a backpacking neighbourhood to an entertainment district: toward a cosmopolitan urban area}

Observations show that in the evenings, especially during weekends, a fringe of young and affluent Vietnamese people, male or female, enjoy the neighbourhood. They socialize with Western people, try to speak English or simply have a drink in a place they consider trendy. The mix between foreign tourist practices and local leisure practices shows that the figure of the backpacker itself is normalized as positive (O'Reilly, 2006): they are less considered as drifters, and more seen as trendy travellers. Our interviewees did not consider the sulphurous reputation of Phạm Ngũ Lão as repellent: it is either minimized ("You just have to pay attention to your belongings or to certain persons, specially when they are drunk" says Thuy, 24 years old) or seen positively, the neighbourhood becoming a good place for amusement: alcohol, sex, drug and more loosened corporeality make the otherness of the neighbourhood pleasant for a night out. The existence of these local practices of leisure also demonstrates that backpacking is not only an economic resource, it also defines its social character and its reputation as a festive, tolerant and cosmopolitan city. 
However, if the growing quality of Phạm Ngũ Lão allows social and urban distinctive practices, it is not specific to this neighbourhood only. For example, globalized food franchises, like Burger King, Starbucks or Mc Donald's, are still quite unusual in Saì Gòn, but they are also present in high-income neighbourhoods like Phú Mỹ Hưng, where they participate to a distinctive urban way of life (Drummond and Thomas, 2003; Nguyen-Marshall et al., 2012). Festivities and decorations for Christmas and New Year are representative of this phenomenon. During those special days, Phạm Ngũ Lão is closed to traffic and Christmas decoration and songs fill the space, while local stakeholders launch special offers and convene parties. These temporary festivities are not only appreciated by Western backpackers missing home, but also by young urban and educated Vietnamese people. To a lesser extent, Halloween and Valentine's Day can also be an occasion to go out in Phạm Ngũ Lão. While these Western festivities were confined to specific places only twenty years ago, the growing consumerism and globalization in H ôChí Minh City explains that they are now more and more celebrated by urban Vietnamese in entertainment places such as malls, cafés or karaoke (Peyvel and Gibert, 2012).

The normalization of Phạm Ngũ Lão can also be explained by growing security concerns, both from the top and the bottom. Residents and shopkeepers display posters on walls inviting tourists not to urinate or to throw their trash. At the same time, authorities have put up some billboards with official socialist slogans such as "Let's build a civilized urban lifestyle", prohibiting certain practices such as smoking, and encouraging using zebra crossings or taking care of one's belongings. The convergence of views between urban authorities and owners can be explained both by the will of the authorities to control the recent urban development more strictly, after decades of laissez-faire, and by the growing worry of middle class people to protect and mark out the boundaries of their newly-acquired properties (Harms, 2009).

\section{From social control to a progressive institutionalized and planned urban fabric in Phạm Ngũ Lão}

Current mutations of the area are also linked with its privileged location in the metropolis. The very first metro line of H ô Chí Minh City, currently under construction, will have a station a stone's throw from Phạm Ngũ Lão. Therefore, the price of land in the area has tremendously increased in the last decade. This uncontrolled increase has been acknowledged by the municipal urban authorities themselves, who classified strategic plots of land under the name of "golden land plots" (đât vàng). These plots are uppermost dedicated to the implementation of mega-projects - such as high-rise buildings, welcoming offices or international luxury hotels. 
In this competitive context, even the biggest actors of the backpacking economy of Phạm Ngũ Lão are seen as minor investors and cannot compete. This shift in the city production at a time of metropolization is to affect greatly the local game in Phạm Ngũ Lão. Even though the neighbourhood has been fostering a vivid tourist economy for decades, this specialization is about to be overtaken by international and upscaled new urban projects, at least as far as the main crossroads and arteries of the area are concerned.

Furthermore, Phạm Ngũ Lão has also been integrated in the H ôChí Minh City historical centre renewal project, won by the Japanese consultant Nikken Seikkei in 2007. The area has also been included in different urban upgrading projects, such as the "Landscaping and Aerial Arrangement of the Walking Area within the City Centre of H ôChí Minh City”, conducted under the supervision of the department of planning and architecture, the Spanish ministry of tourism and trade, and the Idom consulting group, since 2011. Even though all these projects tend to be kept as such for now, they provide an enlightening vision of what Phạm Ngũ Lão is supposed to look like in a near future. All these projects question the current functioning of the backpackers' neighbourhood in many ways. Not surprisingly, the informal use of sidewalks by hawkers is the first element to be challenged: this has been part of the wishes of the metropolitan authorities for many years now, even though it is still a failure (Harms, 2009). These projects also call for the normalization and a move upmarket of every commercial activity.

\section{Figure 7. Conceptual Design for a more standardized Bùi Viện Street}

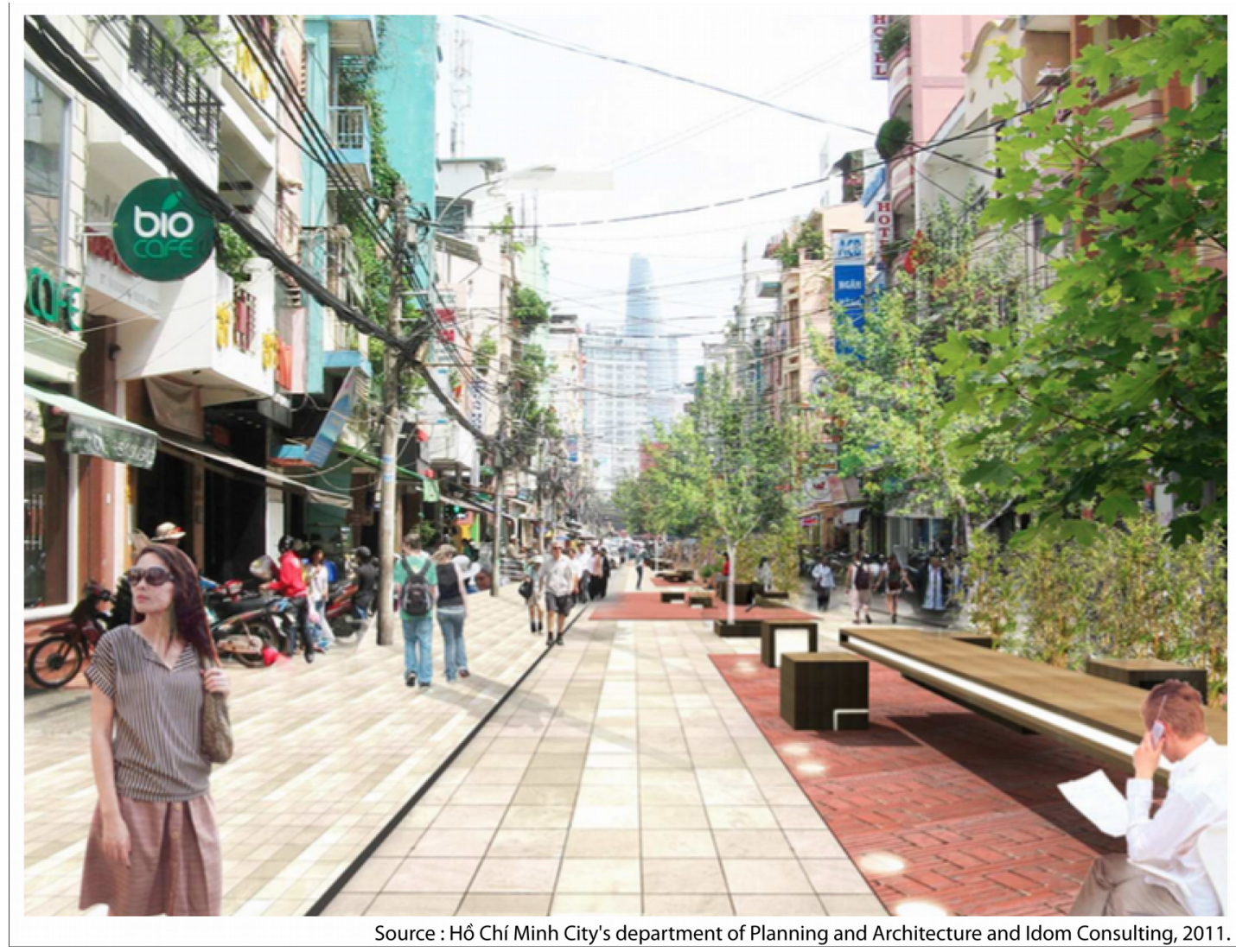


Sketches of this project provide an enlightening vision of what Phạm Ngũ Lão could look like soon (Figure 7). They show the use of standardized urban design elements, such as pedestrian walks, greenery and sustainable development embodiment, such as wooden banks. On this picture, we can also see the call for organic shops, with English language signs. The materials are also very representative of a globalized image of a central metropolitan public space. With these standardized projects, mainly coming from foreign consulting companies, H ôChí Minh City is voluntarily building the image of a globalized metropolis, aligned with international standards.

These projects do not seem to capitalize either on the local experience and how-know in the way to structure a shared activity, or on the way to deal with a subtle gradient on the production and use of public and private space. Due to its strategic location, Phạm Ngũ Lão neighbourhood might embody the classical trajectory of a central location within the metropolization process in the near future. This last point might also constitute a good reason to continue to pay attention to this "urban laboratory" neighbourhood, in order to assess the capacity of its local actors to adapt - and even to take advantage - or not, of this coming new deal in an expanding metropolis.

\section{Conclusion}

Going beyond the classical figure of the enclave, our paper shed a new light on the understanding of backpacking neighbourhoods in the context of the metropolization in Southeast Asia. By crossing tourism and urban studies - through the production of original typo-morphological mapping surveys and comprehensive interviews - our essay engaged with morphological, architectural and landscape analyses and probed into the local spatial apparatus of Phạm Ngũ Lão neighbourhood in H ôChí Minh City.

It shows that Phạm Ngũ Lão is an "ordinary" neighbourhood. Its economic specialization, typical of a Vietnamese city structure, has become the theatre for a competitive and responsive productive system. The focus we proposed on local stakeholders' negotiations to benefit from this backpacking economy reveals the strong "glocalization" of the neighbourhood, with both urban innovations and the reactivation of previous urban forms and economic practices. Hybridizations are then one of the fuels of Phạm Ngũ Lão's daily production. The wealth accumulated through the development of the backpacking economy participates directly to the metropolization process of H ô Chí Minh City: Phạm Ngũ Lão capitalizes profits from a globalized service activity. 
Nevertheless, this activity remains highly unequal and discriminating among the local stakeholders, following spatial, social, gender, racial and age criteria. Our essay shows the current diversification of strategies among local stakeholders and entrepreneurs. This flourishing economy is regulated by complex power relations that polarize rivalry, between private entrepreneurs - both legal and illegal - and with the people's committee of the city. This wealth and the strategic location of the area is sharpening appetites by the urban authorities, leading to the institutionalization of the neighbourhood. Thus, new urban dynamics tend to lead to the integration of this historically backpacking neighbourhood to a broader cosmopolitan leisure area.

\section{Bibliography}

Appadurai, Arjun (1996), Modernity at large: Cultural Dimensions of Globalization. University of Minnesota Press, Minneapolis.

Ariey-Jouglard, Myriam (2011), 'Le service aux tables dans le contexte du développement socioéconomique vietnamien: rapports de pouvoir, harcèlement et exploitation', Recherches féministes, Vol 24, No 2, pp.77-96.

Bennett, Jonathan (2009), 'The Development of Private Tourism Business Activity in the Transitional Vietnamese Economy', in Hitchcock, M., King, V. T. and Parnwell, M., eds, Tourism in Southeast Asia, Challenges and New Directions. University of Hawaii Press, Honolulu.

Bhabha, Homi (1994), The location of culture. Routledge, London.

Chapuis, Amandine (2012), Performances touristiques et production des identités spatiales individuelles à Amsterdam. Ph.D thesis, University Paris 1 Panthéon-Sorbonne.

Chow, Renee (2015), Changing Chinese Cities: The Potentials of Field Urbanism. NUS Press, Singapore.

Cohen, Erik (1973), 'Nomads from Affluence: Notes on the Phenomenon of Drifter Tourism', International Journal of Comparative Sociology, Vol 14, pp. 89-103.

Drummond, Lisa Barbara and Thomas, Mandy (eds) (2003), Consuming Urban Culture in Contemporary Vietnam. Routledge Curzon, London.

Duong, Kim Hong and Ohno, Kenichi (2005), Street Children in Vietnam: Interactions of Old and New Causes in a Growing Economy. Việt Nam Development Forum and GRIPS.

Edensor, Tim (2001), 'Performing Tourism, Staging Tourism (Re)producing Tourist Space and Practice', Tourist Studies, Vol 1, No 1, pp. 59-81. 
Gibert, Marie (2014), Les ruelles de Hô Chí Minh Ville (Việt Nam), Trame viaire et recomposition des espaces publics. Ph.D thesis, University Paris 1 Panthéon-Sorbonne.

Gibert, Marie and Pham Tai, Son (2016), 'Understanding the Vietnamese Urban Fabric from the Inside: a View from Hanoi and Ho Chi Minh City Alleyway Neighbourhoods', The IIAS Newsletter, Vol 73, pp. 32-33.

Gillen, Jamie (2016), Entrepreneurialism and Tourism in Contemporary Vietnam, Lexington Books, Lanham and London,

Hampton, Mark P (1998), 'Backpacker Tourism and Economic Development', Annals of Tourism Research, Vol 25, No 3, pp. 639-60.

Hampton, Mark P and Hamzah, Amran (2010), 'The Changing Geographies of Backpacker Tourism in South-East Asia’, Working Paper Kent Business School, No 10.

Hampton, Mark P (2013), Backpacker Tourism and Economic Development: Perspectives from the Less Developed World, Routledge, London and New York.

Hannam, Kevin and Diekmann, Anya, eds, (2010), Beyond Backpacker Tourism: Mobilities and Experiences. Channel View Publications, Clevedon.

Harms, Erik (2009), 'Vietnam's Civilizing Process and the Retreat from the Street: A Turtle's Eye View From Ho Chi Minh City’, City \& Society, Vol 21 No 2, pp.182-206.

Harms, Erik (2011), Saigon's Edge: On the Margins of Ho Chi Minh City. University of Minnesota Press, Minneapolis.

Hottola, Petri (2005), 'The Metaspatialities of Control Management in Tourism: Backpacking in India', Tourism Geographies, Vol 7, No 1, pp.1-22.

Howard, Robert W (2005), 'Khaosan Road: an Evolving Backpacker Tourist Enclave being Partially Reclaimed by the Locals', International Journal of Tourism Research, Vol 7, No 6, pp. 357-374.

Howard, Robert W (2007), 'Five Backpacker Tourist Enclaves', International Journal of Tourism Research, Vol 9, No 2, pp. 73-86.

Kay Hoang, Kimberly (2015), Dealing in Desire: Asian Ascendancy, Western Decline, and the Hidden Currencies of Global Sex Work. University of California Press, Oakland.

Jenkins, Carson (1982), 'The Effects of Scale in Tourism Projects in Developing Countries', Annals of Tourism Research, Vol 9, No 2, pp. 229-249.

Judd, Dennis R (1999), 'Constructing the Tourist Bubble' in Judd, D. R. and Fainstein, S. S., eds, The Tourist City. Yale University Press, New Haven.

Koh, David W. H. (2001), 'Negotiating the Socialist State in Vietnam through Local Administrators: The Case of Karaoke Shops', SOJOURN, Vol 12, No 2, pp. 279-305. 
Lefebvre, Henri (1991), The Production of Space, Blackwell, Malden.

Lloyd, Kate (2003), 'Contesting Control in Transitional Vietnam: The Development and Regulation of Traveller Cafés in Hanoi and Ho Chi Minh City', Tourism Geographies, Vol 5, No 3, pp. 350-66.

Lloyd, Kate (2006), 'Catering to the Backpacker: Enclaves in Vietnam', Tourism recreation research, Vol 31, No 3, pp. 65-73.

Munt, Ian (1994), 'Eco-tourism or Ego-tourism?’, Race \& Class, Vol 36, No 1, pp. 49-60.

Nguyen-Marshall, Van, Drummond, Lisa B. and Bélanger Danièle, eds, (2012), The Reinvention of Distinction. Modernity and the Middle Class in Urban Vietnam, Springer, Dordrecht.

O’Reagan, Michael (2010), 'Backpacker Hostels: Place and Performance', in Hannam, K. and Diekmann, A., eds, Beyond Backpacker Tourism, Mobilities and experiences. Channel View Publications, Bristol.

O'Reilly, Camille Caprioglio (2006), 'From Drifter to Gap Year Tourist: Mainstreaming Backpacker Travel', Annals of Tourism Research, Vol 33, No 4, pp. 998-1017.

Parnell, Susan and Oldfield, Sophie, eds, (2014), The Routledge Handbook on Cities of the Global South. Routledge, New York.

Perera, Nihal and Tang, Wing-Shing, eds, (2012), Transforming Asian Cities: Intellectual Impasse, Asianizing Space, and Emerging Translocalities. Routledge, New-York.

Pearce, Douglas (1989), Tourist Development. Harlow, Longman.

Pearce Philip L, Murphy, Laurie and Brymer, Eric (2009), 'Evolution of the Backpacker Market and the Potential for Australian Tourism', Cooperative Research Centre for Sustainable Tourism, Queensland.

Peyvel, Emmanuelle (2009), L'émergence du tourisme domestique au Vietnam : lieux, pratiques et imaginaires. $\mathrm{PhD}$ thesis, University Nice Sophia-Antipolis.

Peyvel, Emmanuelle and Gibert, Marie (2012), 'Đi chới đi! Entre public et privé, une approche socio-spatiale des pratiques de loisirs à H ồChí Minh Ville’, EchoGéo, No 21.

Peyvel, Emmanuelle and Võ Sang, Xuân Lan (2016), ‘Tourism, Urbanisation and Globalisation in Vietnam', The IIAS Newsletter, Vol 73, pp. 38-39.

Quỳnh Trân, Tôn Nữ and Nguyễn Trọng, Hòa (2007), Văn hoá hẻm phố Sài Gòn - thành phố Hô Chí Minh, Nhà xuát bản Tổng hợp, H ô Chí Minh City.

Richards, Greg and Wilson, Julie, eds, (2004), The Global Nomad: Backpacker Travel in Theory and Practice. Channel View Publications, Clevedon.

Robinson, Jennifer (2006), Ordinary Cities: Between Modernity and Development. Routledge, London and New York.

Roy, Ananya and Ong, Aihwa, eds, (2011), Worlding cities: Asian Experiments and the Art of Being Global. Wiley-Blackwell, Oxford. 
Scheyvens, Regina (2002), 'Backpacker Tourism and Third World Development', Annals of Tourism Research, Vol 29, No 1, pp. 144-64.

Statistical Year Book of Ho Chi Minh City in 2013. Statistical Publishing House, Ho Chi Minh City.

Tracol-Huynh, Isabelle (2013), 'Entre ordre colonial et santé publique, la prostitution au Tonkin colonial de 1885 à 1954'. Ph.D thesis, University of Lyon 2, Lyon.

Welk, Peter (2010), 'Town of 1770, Australia - The Creation of a New Backpacker Brand', in Hannam, K. and Diekmann, A., eds, Beyond Backpacker Tourism, Mobilities and experiences. Channel View Publications, Bristol.

Wilson, Julie and Richards Greg (2008), 'Suspending Reality: An Exploration of Enclaves and the Backpacker Experience', Current Issues in Tourism, Vol 11, No 2, pp. 187-202. 